\title{
ECTOPIC PREGNANCY;
}

FMHEXPERIENCEOFSUCCESSRATEOFSINGLEDOSEOFMETHOTREXATE FOR THE MEDICAL MANAGEMENT OF ECTOPIC PREGNANCY

1. MBBS, MRCOG, FRCOG Associate Professor Department of Gynae, Fatima Memorial Hospital Lahore.

2. MBBS, FCPS

Professor

Department of Gynae,

Fatima Memorial Hospital Lahore.

3. MBBS, FCPS

Medical Officer

Department of Gynae,

Fatima Memorial Hospital Lahore.

Correspondence Address:

Dr. Fareeha Khaliq Khan

Department of Gynae,

Fatima Memorial Hospital Lahore.

drfareeha@hotmail.com

Article received on:

21/09/2017

Accepted for publication:

15/05/2018

Received after proof reading:

00/00/2018

\section{Fareeha Khaliq Khan ${ }^{1}$, Rubina Iqbal $^{2}$, Zaibunnisa ${ }^{3}$}

\begin{abstract}
Introduction: Medical treatment is the first step in the treatment of ectopic pregnancy (EP) now days. Medical treatment with Methotrexate for EP is safe and effective method without the risks associated with the surgical procedure. Objectives: To determine the success rate of single dose of Methotrexate for medical management of females presenting with EP. Study Design: Quasi trial study. Setting: Department of Obstetrics \& Gynaecology, Fatima Memorial hospital, Lahore. Period: 1 year from September 2014 till August 2015. Material \& Methods: Study design was prospective descriptive case series in which a total of 140 women, age $20-45$ years of any parity with confirmed EP, were included. Females were prescribed Methotrexate $50 \mathrm{mg} / \mathrm{m}^{2}$, as a single dose. $\beta$-HCG level was measured again at 7 th day. If $\beta-H C G$ was decreased by $>15 \%$ of baseline levels and decrease in the size of mass on USG, then success was labeled. Data was entered and analyzed using computer program SPSS version 20. Results: Mean age of women in this study was $32.38 \pm 6.34$ years. At 3rd day post-treatment day, mean level of $\beta-H C G$ was $2019.51 \pm 293.39$ and at 7 th day, mean $\beta$-HCG level was $1127.44 \pm 403.78$. At 7 th day, there were $125(89.3 \%)$ patients whose $\beta$-HCG level was decreased by $>15 \%$ and success was labelled. Conclusion: Based on findings of this study it can be concluded that Methotrexate can be used as first line management protocol for EP as it was successful in a high percentage of patients.
\end{abstract}

Key words: Medical Management, Methotrexate, Single Dose, Success Rate, Tubal Ectopic Pregnancy.

Article Citation: Khan FK, Iqbal R, Zaibunnisa. Ectopic pregnancy; FMH experience of success rate of single dose of methotrexate for the medical management of ectopic pregnancy. Professional Med J 2018; 25(8):1164-1167. DOI:10.29309/TPMJ/18.4334

\section{INTRODUCTION}

Ectopic pregnancy (EP) represents $1.5-2 \%$ of all pregnancies and is an imperative reason for morbidity among females within reproductive age group. Early and successful treatment of EP is important as it saves the patients from many upcoming complications. Medical treatment is the first step in the treatment of EP now days. ${ }^{1-3}$ Medical treatment with Methotrexate for EP is safe and effective method without the risks associated with the surgical procedure. Regarding medical management, Methotrexate was first perceived as a potential treatment for unruptured EP in 1982 and is being used successfully for treatment of EP as an alternative to surgery. ${ }^{4-6}$ There are 3 treatment regimens of Methotrexate available: the multi-dose conventional treatment, one dose treatment and 2-dose treatment.7,8 The objective of this study was to assess the success rate of single dose of Methotrexate for medical management of females presenting with EP.

\section{MATERIALS \& METHODS}

It was a Quasi experimental conducted at the Department of Obstetrics \& Gynaecology, Fatima Memorial hospital, Lahore. The Duration of study was one year, from September, 2014 to August, 2015. After approval from Ethical board of the hospital, this study was started. A sample size of 140 cases was calculated with $95 \%$ confidence level, $8 \%$ margin of error and taking expected percentage of success i.e. $65 \%$ with Methotrexate for medical management of females presenting with EP. ${ }^{9}$ Sampling technique used was nonprobability consecutive sampling. EP was defined as presence of gestational sac outside the uterine cavity confirmed by ultrasound and positive hCG $>1500 \mathrm{IU} / \mathrm{L}$. Also in this study, success was 
measured by more than $15 \%$ decrease in beta hCG levels at $1^{\text {st }}$ and $7^{\text {th }}$ day after administration of single dose of Methotrexate. We included all female patients of age 20-45 years of any parity with confirm EP (positive hCG>1500IU/L and tubal mass on Ultrasonography) presented at gestational age $<12$ weeks (on LMP). Our exclusion criteria included:

- Females having allergy with Methotrexate; females with hemoperitoneum $>100 \mathrm{ml}$;

- Females with adnexal mass $>5 \mathrm{~cm}$ and presence of cardiac activity;

- Females with B-hCG >5000 IU/L; females with chronic hypertension $(B P \geq 140 / 90 \mathrm{mmHg})$;

- Deranged LFTs (AST>40IU, ALT>40IU); deranged RFTs (serum creatinine $>1.2 \mathrm{gm} / \mathrm{dl}$ );

- And low WBCs $(<4500 \mu \mathrm{L})$.

Informed consent for inclusion in this study was obtained from all patients. Demographic details (name, age, parity, gestational age) were obtained. Then females were prescribed Methotrexate $50 \mathrm{mg} / \mathrm{m}^{2}$, intramuscular injection, as a single dose. $\beta-\mathrm{HCG}$ level was measured again at $1^{\text {st }}$ and $7^{\text {th }}$ day. If $\beta$-HCG levels decreased by $>15 \%$ of baseline $\beta$-HCG levels then success was labeled. All this information was recorded on proforma. Data was analyzed using computer program SPSS version 20. Mean and standard deviation was calculated for the quantitative variables like age and gestational age. Frequencies and percentages were calculated for parity and success. Data was stratified for BMI (underweight, normal, overweight). Stratified groups were compared by using chi-square test taking $p$-value $\leq 0.05$ as significant.

\section{RESULTS}

Mean age of women in this study was $32.38 \pm 6.34$ years (range: $20-45$ years). Mean gestational age of women in the study was $7.66 \pm 1.81$ weeks (range being 5-11 weeks). Among 140 women, most of them were multiparous. All details are given in Table-I.

At $1^{\text {st }}$ day post treatment, mean level of $\beta-H C G$ was $2019.51 \pm 293.39 \mathrm{IU} / \mathrm{L}$ and at $7^{\text {th }}$ day mean $\beta-H C G$ level was $1127.44 \pm 403.78 \mathrm{IU} / \mathrm{L}$. At this point it can be seen that $\beta-H C G$ level decreases as compared to that of $3^{\text {rd }}$ day. At $1^{\text {st }}$ day minimum and maximum level of $\beta$-HCG was $1500 \mathrm{IU} / \mathrm{L}$ and $2496 \mathrm{IU} / \mathrm{L}$ and at $7^{\text {th }}$ day minimum and maximum $\beta$-HCG level was $596 \mathrm{IU} / \mathrm{L}$ and $2301 \mathrm{IU} / \mathrm{L}$. As per operational definition cut point for success of $\beta-\mathrm{HCG}$ level at $7^{\text {th }}$ day there were 125 (89.3\%) patients whose $\beta$-HCG level was decreased by $>15 \%$. However, in the remaining $15(10.7 \%)$ patients $\beta$-HCG level was decreased by $<15 \%$. As per operational definition success of treatment was seen in 125 (89.5\%) patients. Patients who had success with Methotrexate were stratified according to body mass index (BMI) and no statistically significant result was seen Table-II.

\begin{tabular}{|l|c|}
\hline Age $($ mean \pm SD) & $32.38 \pm 6.34$ years \\
\hline Gestational Age (mean \pm SD) & $7.66 \pm 1.81$ week \\
\hline Parity (n (\%) & $38(27.14 \%)$ \\
Nuliparous & $102(72.8 \%)$ \\
Multiparity & $38(27.1 \%)$ \\
1 & $42(30 \%)$ \\
2 & $22(15.7 \%)$ \\
3 &
\end{tabular}

Table-I. Demographic details of patients

\begin{tabular}{|c|c|c|c|c|}
\hline \multirow{2}{*}{ Body Mass Index } & \multicolumn{2}{|c|}{ Success of Treatment } & \multirow{2}{*}{ Total } & \multirow{2}{*}{ P-Value } \\
\hline & Yes & No & & \\
\hline Underweight & $46(36.8 \%)$ & $4(26.7 \%)$ & 50 & \multirow{4}{*}{0.092} \\
\hline Normal & $46(36.8 \%)$ & $3(20 \%)$ & 49 & \\
\hline Overweight & $33(26.4 \%)$ & $8(53.3 \%)$ & 41 & \\
\hline Total & 125 & 15 & 140 & \\
\hline
\end{tabular}




\section{DISCUSSION}

EP is defined as pregnancy outside of the uterine cavity. It is a potential life threatening condition which may have devastating effects on maternal outcomes. Its incidence has increased all over the worldwide recently. Like advancements in all disease, EP is also mostly being treated by a lot of conservative measures. The most common location of EP is the fallopian tube followed by cervical, interstitial, hysterotomy scar, intramural, ovarian, or abdominal. Methotrexate is now being commonly used and is considered as first line treatment modality for EP. ${ }^{10-12}$

Several studies to determine factors associated with the success or failure of response to treatment have been done. Women most likely to respond to Methotrexate therapy are thought to be those with small gestational masses, lower serum concentrations of human chorionic gonadotropin and progesterone, and the absence of blood in the peritoneal cavity, but there is controversy in previous studies to determine the true effect of these characteristics on success rates. ${ }^{13,14}$

In this study, success rate of Methotrexate therapy for EP was $89 \%$. The success rate of Methotrexate is in line with the results of other studies who had assessed the success rate of Methotrexate for treating EP. Potter et al reported a success rate of $85 \%\left(69 / 81\right.$ patients) ${ }^{15}$, this was $72.4 \%(63 / 87)$ in Ustunyurt et al. ${ }^{16}$ An Iranian study reported the success rate of Methotrexate for treating EP was $77 \% .{ }^{17}$

There is a continuous effort going on to treat EP with minimal invasive measurements. Recently, Gupta M reported the success of intra-sac injection of local KCL and systemic Methotrexate for the successful management of EP. ${ }^{18}$ In Potter et al study, the median pretreatment serum beta-human chorionic gonadotropin level was lower in those women in whom treatment was successful compared with those women with treatment failure (793 vs. $3804 \mathrm{mlU} / \mathrm{mL}$, $\mathrm{p}<0.002)$, similar to Ustunyurt et al study, $(1,417 \mathrm{mlU} / \mathrm{mL}$ vs. $5,995 \mathrm{mlU} / \mathrm{mL}, \mathrm{p}<0.001) .{ }^{15,16}$ Regarding the successfulness of treatment, most common used definition is decrease of $15 \%$ or
$20 \%$ of $\beta-H C G$ serum levels. In this study, we have used the same operational definition. However, another study recently has shown that any decrease in $\beta$-HCG serum levels between 1 and 7 days after start of treatment with Methotrexate may also be used as an alternative. ${ }^{11}$

Results of this study confirmed the success rate of a single dose of Methotrexate for medical management of patients presenting with EP. Based on these results now Methotrexate is a reliable drug not only as a first line medical management it is also help full for reduction of unnecessary surgical interventions.

\section{CONCLUSION}

Based on the findings of this study it can be concluded that Methotrexate therapy is a successful first line medical treatment modality for tubal ectopic pregnancies. The controversy regarding the effectiveness of Methotrexate is clear now and this can be used effectively for treating ectopic pregnancies as well as to avoid unnecessary surgical interventions for the patients.

\section{Copyright@ 15 May, 2018.}

\section{REFERENCES}

1. Kwon JH, Kim GM. Safety and efficacy of uterine artery embolization in ectopic pregnancies refractory to systemic methotrexate treatment: A single-center study. 2017;40:1351-57.

2. Qayyum H, Ramlakhan S, Keriakos R, Gunasekaran B. Ruptured ectopic pregnancy with a negative urinary pregnancy test after methotrexate treatment - challenges of diagnosis in the emergency department. J Obstet Gynaecol. 2017;37:958-59.

3. Uludag SZ, Kutuk MS, Aygen EM, Sahin Y. Conservative management of cervical ectopic pregnancy: Single-center experience. J Obstet Gynaecol Res. 2017;43:1299-304.

4. Cymbaluk-Ploska A, Chudecka-Glaz A, Kuzniak $\mathrm{S}$, Menkiszak J. Ectopic pregnancy treatment by combination therapy. Open Med (Wars). 2016;11:53036.

5. Di Spiezio Sardo A, Vieira MDC, Lagana AS, Chiofalo B, Vitale SG, Scala M, et al. Combined Systemic and Hysteroscopic Intra-Amniotic Injection of Methotrexate Associated with Hysteroscopic 
Resection for Cervical Pregnancy: A Cutting-Edge Approach for an Uncommon Condition. Eurasian J Med. 2017;49:66-68.

6. Tas EE, Akcay GF, Avsar AF. Single-dose methotrexate for the treatment of ectopic pregnancy: Our experience from 2010 to 2015. Pak J Med Sci. 2017;33:13-17.

7. Kim J, Jung YM, Lee DY, Jee BC. Pretreatment serum human chorionic gonadotropin cutoff value for medical treatment success with single-dose and multi-dose regimen of methotrexate in tubal ectopic pregnancy. 2017;60:79-86.

8. Song T, Kim MK, Kim ML, Jung YW, Yun BS, Seong SJ. Single-dose versus two-dose administration of methotrexate for the treatment of ectopic pregnancy: A randomized controlled trial. Obstet Gynecol Sci. 2016;31:332-8.

9. Tawfiq A, Agameya A-F, Claman P. Predictors of treatment failure for ectopic pregnancy treated with single-dose methotrexate. Fertility and sterility. 2000;74:877-80.

10. Soysal S, Anik Ilhan G, Vural M, Yildizhan B. Severe methotrexate toxicity after treatment for ectopic pregnancy: A case report. Turk J Obstet Gynecol. 2016;13:221-23.

11. Sukur YE, Koyuncu K, Seval MM, Cetinkaya E, Dokmeci F. Comparison of alternative betahCG follow-up protocols after single-dose methotrexate therapy for tubal ectopic pregnancy. Arch Gynecol Obstet. 2017;296:1161-65.
12. Tian N, Yu J, Zhang S, Ma WY, Wang T, Wang YM. Effects of methotrexate on the quality of oocyte maturation in vitro. Eur Biophys J. 2017.

13. Lipscomb GH, McCord ML, Stovall TG, Huff G, Portera SG, Ling FW. Predictors of Success of Methotrexate Treatment in Women With Tubal Ectopic Pregnancies. Obstetrical \& Gynecological Survey. 2000;55:363-64.

14. Levin G, Saleh NA, Haj-Yahya R, Matan LS, Benshushan A. Predicting success of methotrexate treatment by pretreatment HCG level and 24-hour HCG increment. Int J Gynaecol Obstet. 2017.

15. Potter MB, Lepine LA, Jamieson DJ. Predictors of success with methotrexate treatment of tubal ectopic pregnancy at Grady Memorial Hospital. American journal of obstetrics and gynecology. 2003;188:119294.

16. Ustunyurt E, Duran M, Coskun E, Ustunyurt ÖB, Şimşek H. Role of initial and day 4 human chorionic gonadotropin levels in predicting the outcome of single-dose methotrexate treatment in women with tubal ectopic pregnancy. Archives of gynecology and obstetrics. 2013;288:1149-52.

17. Mirbolouk F, Yousefnezhad A, Ghanbari A. Predicting factors of medical treatment success with single dose methotrexate in tubal ectopic pregnancy: a retrospective study. Iranian journal of reproductive medicine. 2015;13:351.

18. Gupta M, Kriplani A, Mahey R, Kriplani I. Successful management of caesarean scar live ectopic pregnancies with local KCL and systemic methotrexate. BMJ Case Rep. 2017;2017.

\begin{tabular}{|c|l|l|c|}
\hline \multicolumn{3}{|c|}{ AUTHORSHIP AND CONTRIBUTION DECLARATION } \\
\hline Sr. \# & \multicolumn{1}{|c|}{ Author-s Full Name } & Contribution to the paper & Author=s Signature \\
\hline 1 & Fareeha Khaliq Khan & Writer & Jamban \\
2 & Rubina lqbal & Writer & Rubunger \\
3 & Zaibunnisa & Writer & Zait-Nise \\
\hline
\end{tabular}

